\title{
PROFESOR ZW. DR HAB. WLODZIMIERZ PIOTROWSKI
}

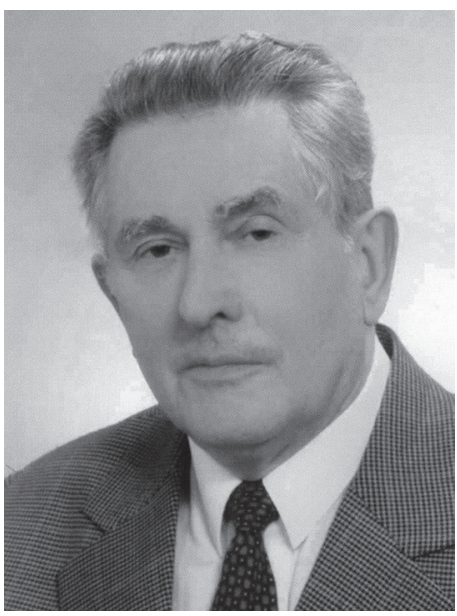

Pracownicy Katedry Prawa Pracy i Prawa Socjalnego, społeczność Wydziału Prawa i Administracji i całego Uniwersytetu im. Adam Mickiewicza w Poznaniu oraz środowisko naukowe prawa pracy i prawa socjalnego w Polsce z wielkim żalem przyjęły wiadomość o śmierci 15 marca 2014 prof. dr. hab. Włodzimierza Piotrowskiego, powszechnie znanego, wybitnego naukowca, znaczącej postaci w rozwoju powojennego prawa pracy w Polsce.

Profesor Włodzimierz Piotrowski urodził się 25 sierpnia 1931 r. w Kowalewie Pomorskim. W latach 1949-1954 studiował prawo na Wydziale Prawa i Administracji UAM. Tytuł magistra uzyskał na podstawie pracy $W y$ właszczenie jako instrument gospodarki planowej, napisanej pod kierunkiem prof. dr. hab. Mariana Zimmermana. Po ukończeniu studiów podjął pracę w Katedrze Prawa Administracyjnego - Zakładzie Prawa Pracy UAM, a od 1955 r. zaczął wykonywać zawód radcy prawnego. W latach 1962-1964 odbył aplikację adwokacka. Na podstawie rozprawy doktorskiej dotyczącej ochrony trwałości

stosunku pracy i roszczeń pracownika pozbawionego miejsca pracy, przygotowanej pod opieka naukową prof. dr. hab. Wiktora Jaśkiewicza, uzyskał w 1964 r. stopień doktora oraz objął stanowisko adiunkta, a w 1969 r. - stanowisko docenta. Kolejny etap drogi naukowej Profesora Włodzimierza Piotrowskiego wyznacza 1977 r., kiedy to na podstawie oceny dorobku naukowego oraz pracy habilitacyjnej Stosunek pracy. Zagadnienia prawne nawiazania, zmiany, ustania i treści uzyskał stopień doktora habilitowanego. W 1988 r. na mocy uchwały Rady Państwa otrzymał nominację na profesora nadzwyczajnego, a w 2001 r. obją stanowisko profesora zwyczajnego.

Profesor Włodzimierz Piotrowski przez wszystkie lata pracy na Uczelni był bardzo aktywny i zaangażowany w życie Wydziału i Uniwersytetu, co wiązało się z pełnieniem wielu funkcji, m.in. kierownika Katedry Prawa Pracy (1982-2001) przekształconej z Jego inicjatywy w Katedrę Prawa Pracy i Prawa Socjalnego, rzecznika prasowego Rektora UAM (1985-1988) oraz przewodniczącego Komisji Prawnej Senatu UAM (1998-1999). Uczestniczył w przygotowawczych pracach legislacyjnych: był współautorem projektu ustawy o ochronie zdrowia psychicznego, projektu ustawy o ochronie roszczeń pracowniczych w razie niewypłacalności pracodawcy oraz ustawy o komornikach sądowych. Profesor Włodzimierz Piotrowski pełnił zaszczytne funkcje w organach państwowych - był m.in. członkiem Komisji do Spraw Reformy Prawa Pracy (1981-1999) oraz Rady Legislacyjnej przy Prezesie Rady Ministrów (1987-1992).

Zasługi naukowe i organizacyjno-dydaktyczne Profesora Włodzimierza Piotrowskiego były podstawą do przyznania Mu wielu nagród, m.in. nagrody Głównego Inspektora Pracy za działalność na rzecz ochrony pracy (1992), nagrody Rektora UAM za działalność naukową (1990) i organizacyjną (1988 i 1989) oraz odznaczeń: Złotego Krzyża Zasługi (1970), Krzyża Kawalerskiego Odrodzenia Polski (1976) i Krzyża Oficerskiego Odrodzenia Polski (1985).

Dorobek naukowy Profesora Włodzimierza Piotrowskiego zajmuje ważne miejsce w doktrynie prawa pracy i prawa socjalnego. W tworzenie teoretycznej refleksji nad szeroko rozumianymi problemami zatrudnienia Profesor włączył się wraz z pierwszym pokoleniem osób wykształconych po II wojnie światowej. Na Uniwersytecie Poznańskim (obecnie Uniwersytecie im. Adama Mickiewicza) pracował od 1954 r. Należał do ekskluzywnego i coraz mniej licznego - ze względu na nieubłagany upływ czasu - grona uczestników wszystkich ogólnopolskich zjazdów katedr prawa pracy, które rozpoczęły pierwsze spotkania nielicznej grupy osób w Zamościu i Kołobrzegu. Począwszy od pierwszego opracowania książkowego Nowe warunki rozwiazania stosunku pracy (1957), przez wiele fundamentalnych monografii i opracowań, Profesor wniósł znaczący wkład do rozwoju instytucji polskiego prawa pracy, przedstawiając analizę teoretyczną, jak też angażując się w praktykę tworzenia i stosowania prawa. Profesor nigdy nie odcinał się od potrzeb praktyki, 
mając poczucie obowiązku udzielenia pomocy w adaptacji teoretycznych założeń doktryny prawa pracy zarówno w dziedzinie legislacji, jak i stosowania prawa.

Profesor Włodzimierz Piotrowski należał do rzadkiego już typu uczonego, który swojej aktywności nie ogranicza do wąskiego pola podstawowych naukowych zainteresowań. Prezentował szeroką refleksję prawoznawczą ponad formalnymi podziałami na gałęzie prawa i dziedziny nauki. Głównym polem zainteresowania Profesora było prawo pracy, ale jako jeden z pierwszych na równi włączył do podejmowanego zakresu badawczego problematykę ubezpieczeń społecznych (wprowadzając zarazem na grunt polski pojęcie prawa socjalnego i promując jego uznanie za osobna gałą́ prawa). Analiza społecznych przesłanek kształtowania się regulacji prawnych, jak też społecznych skutków obowiązywania norm prawnych doprowadziła Profesora do podjęcia i długoletniej pracy nad problematyka polityki społecznej. W ostatnich latach pracy Profesor wiele zainteresowania poświęcił kwestii przyczyn, przebiegu i skutków przemian gospodarczych związanych z globalizacją, a także ich wpływu na kształtowanie się ustroju pracy.

Wśród głównych tematów badawczych, jakie podejmował, wskazać należy zagadnienia rozwiązania stosunku pracy i ochronę jego trwałości, którą to kwestię jako pierwszy opracował w naukowej monografii $Z$ problematyki ochrony trwałości stosunku pracy (1965). Rozważania te uzupełnił monografią Roszczenia pracownika z tytutu pozbawienia go miejsca pracy (1966). Kwestie tego zakresu podejmował w kontekście zmieniającego się stanu prawnego przez cały okres naukowej aktywności, w sumie w kilkunastu późniejszych artykułach i glosach. Zajmował się też różnymi aspektami treści stosunku pracy, w jego dorobku są artykuły dotyczące wynagrodzeń, urlopów, świadczeń rodzicielskich, statusu prawnego dyrektora przedsiębiorstwa państwowego i kierownika zakładu opieki zdrowotnej. Swe poglądy dotyczące stosunku pracy po wejściu w życie Kodeksu pracy z 1974 r. zebrał w monografii Stosunek pracy. Zagadnienia prawne nawiazania, zmiany, ustania i treści (1977).

Drugim szerokim polem zainteresowań naukowych Profesora Piotrowskiego, z którym był także bardzo związany jako jeden z prekursorów tej dziedziny nauki w Polsce, były prawne zagadnienia ubezpieczeń społecznych. Z licznych publikacji Profesora poświęconych tej problematyce trzeba przypomnieć dwa artykuły opublikowane w „Ruchu Prawniczym, Ekonomicznym i Socjologicznym". Rozważania zaprezentowane w tekstach Uwagi na temat programu reformy ubezpieczeń spotecznych w Polsce (1995) i Niektóre aspekty prawne reformy systemu emerytalnego (1999) podważały powszechne wówczas przekonanie o dobroczynnych skutkach właśnie wprowadzanej trójfilarowej koncepcji systemu emerytalnego. Krytyka w nich zaprezentowana wynikała jednak z rzetelnej i dogłębnej analizy wprowadzanych zmian systemu emerytalnego, których Profesor nie popierał, a które obecnie stopniowo są wycofywane. Sądzę, że śledzenie wydarzeń z tego zakresu nie dałoby $\mathrm{Mu}$ satysfakcji, lecz spowodowało żal, że Jego przemyślenia nie pozwoliły uniknąć błędów przed ich popełnieniem.

Zainteresowanie problematyką polityki społecznej przywiodło Profesora do podejmowania, i to wielokrotnie, zagadnień tak odległych od głównego nurtu badań nad prawem pracy, jak problematyka ochrony zdrowia psychicznego, statusu prawnego osób upośledzonych umysłowo, pojęcia rodziny niepełnej i przyczyn niepełności rodzin.

Szerokie horyzonty myślowe, wielka wiedza prawnicza oraz umiejętność ciekawego i inspirującego przekazania myśli powodowały, że Profesor był znakomitym opiekunem młodzieży. Wiele osób z różnych pokoleń zostało zainspirowanych i wręcz uwiedzionych wizjonerskimi opowieściami Profesora przedstawiającymi nieograniczone możliwości naukowej eksploracji uprawianych przez Niego dziedzin nauki. Należy do nich także piszący te słowa. Osoby, które dobrze znały Profesora Piotrowskiego, zdawały sobie sprawę, jak wielką stratą jest to, że Profesor - bardzo zaabsorbowany sprawami prywatnymi i organizacyjnymi - nie przykładał w ostatnich latach należytej wagi do utrwalenia swych przemyśleń w formie publikacji. Wielogodzinne spotkania i naukowe dyskusje znalazły jednak odbicie w dorobku Jego wychowanków.

Profesor Włodzimierz Piotrowski był życzliwym, hojnym i cierpliwym opiekunem naukowym. Hojnym, gdyż przekazywał młodym swe cenne spostrzeżenia i pomysły na naukowe opracowania oraz wskazywał warte podjęcia zakresy problemowe, ciesząc się i chwaląc ich sukcesami. Nie dążył do opracowywania wszystkich swych pomysłów samodzielnie, wręcz przeciwnie, bardzo cenił i w pełni słusznie także za swoje sukcesy uważał nasze publikacje, do których wniósł wkład jako inspirator czy pierwszy nieformalny recenzent. Hojnie szafował także swym czasem, cierpliwie znosząc liczne i długie domowe wizyty pożądających dyskusji i wymiany poglądów wychowanków. 
Wielką zaletą tych rozmów była często prezentowana przez Profesora życzliwa krytyka, która pokazywała zainteresowanemu niedostatki jego koncepcji, dając szansę na ich ulepszenie. Wszystkie osoby współpracujące z Profesorem wiedziały, że mogą liczyć na wnikliwe zainteresowanie i inspirująca dyskusję o kontrowersyjnych sprawach naukowych. Intelektualne i duchowe wsparcie, które od Niego otrzymywaliśmy, było nieocenione.

Szeroko otwarta dla poszukujacych literatury była bogata biblioteka Profesora. Grubo ponad półwiecze gromadzenia naukowych materiałów sprawiło, że każda biblioteka chciałaby mieć choć część tych zbiorów. Profesor nie tylko wypożyczał poszukującym trudno dostępne pozycje, ale wręcz zachęcał do wypożyczenia innych, wskazując, bez lektury jakich książek wiedza zainteresowanego będzie niepełna. Ponieważ wymagania Profesora w tym zakresie były duże, nieraz wychodziło się od Niego obładowanym obowiązkową lektura, zastanawiając się, kiedy nadejdzie czas, aby coś napisać, jeśli będzie się chciało to wszystko przeczytać...

Cztery lata temu świętowaliśmy 55-lecie pracy naukowej Profesora Piotrowskiego. Liczyliśmy wtedy na jeszcze wiele lat Jego twórczej aktywności i inspirującej obecności w Katedrze. Bowiem być naukowcem i uczonym to nie to samo. Naukowcem jest każda osoba prowadząca badania według przyjętej metodologii, mniej czy bardziej udatnie. Uczonych jest niewielu, to naukowcy o uznanym i cenionym dorobku, będący wzorem dla innych jako ludzie żyjący nauką. Taki był Profesor Włodzimierz Piotrowski. 